\title{
PURIFICATION AND SOME PROPERTIES OF TWO ACID RIBONUCLEASES FROM THE MYCELIA OF ASPERGILLUS NIGER
}

\author{
YOSHIKATA NOMACHI ${ }^{1}$ AND TERUYA KOMANO ${ }^{2}$ \\ Department of Biology, Faculty of Science, \\ Tokyo Metropolitan University, Setagaya-ku, Tokyo
}

(Received July 24, 1980)

\begin{abstract}
Acid ribonuclease (RNase) was extracted from mycelia of Aspergillus niger 1617 and separated into two fractions designated acid RNases I (EC 3.1.27.1) and II (EC 3.1.27.3). Each fraction was partially purified and its enzymatic properties were examined. The molecular weight of acid RNase I was approximately 45,000 , and that of II was 13,000 . The optimal pH of acid RNase I was 3.5 and that of II, 4.5. Acid RNase I was inhibited markedly by $\mathrm{Fe}^{3+}, \mathrm{Cu}^{2+}, \mathrm{Hg}^{2+}$ and $5^{\prime}$-ATP, whereas II was inhibited markedly by $\mathrm{Fe}^{3+}$. Acid RNase I had no base specificity producing $3^{\prime}$-monophosphates of the four nucleosides and guanosine2',3'-cyclic monophosphate. Acid RNase II was a guanine-specific RNase.

Changes in the activity of acid RNases I and II were studied during culture on agar medium. The activity of acid R Nases I and II increased and reached their maxima during the late phase of active growth. After their maxima, the activity of acid RNase I remained unchanged, while that of II decreased and finally disappeared.
\end{abstract}

Ribonucleases (RNases) of fungi have been studied widely in the recent two decades. Many RNases have been reported to occur in fungi such as Aspergillus niger (1), A. oryzae (RNases $\mathrm{T}_{1}$ and $\mathrm{T}_{2}$ ) (2,3), A. saitoi (RNase M) (4), Aspergillus species (RNase L) $(5,6)$, Neurospora crassa (RNases $\mathrm{N}_{1}, \mathrm{~N}_{2}$ and $\left.\mathrm{N}_{3}\right)(7,8)$, Ustilago sphaerogena (RNases $\mathrm{U}_{1}, \mathrm{U}_{2}, \mathrm{U}_{3}$ and $\left.\mathrm{U}_{4}\right)(9,10)$, Rhizopus species (RNase $\mathrm{R}$ ) (11) and so on. However, few studies have been reported on the changes in RNase activity in relation to fungal growth. NAGASAKI (1) described changes in the activities of various enzymes accompanied by phosphorus metabolism in relation to the culture age of mycelia of $A$. niger. He found that $A$. niger mycelia produced

1 Present address: Tanabe Seiyaku Co. Ltd., Tokyo.

2 Mailing address: Dr. T. Komano, Dept. of Biology, Faculty of Science, Tokyo Metropolitan Univ., 1-1, Fukasawa 2-chome, Setagaya-ku, Tokyo 158. 
at least two RNases of different $\mathrm{pH}$ optima. Activity of an enzyme having its optimum at pH 6.0 was found from the beginning of the culture, and that of another, $\mathrm{pH} 4.5$ was biphasic during the culture.

We found that the acid RNase active around $\mathrm{pH} 4$ from $A$. niger consisted of two different RNases. The present paper describes purification and some properties of the two acid RNases in A. niger together with the changing patterns of their activities during culture.

\section{MATERIALS AND METHODS}

Organism and cultivation. Aspergillus niger 1617 was used as a test organism throughout this study. The agar medium employed was composed of sodium-Lglutamate, $0.3 \mathrm{~g}$; DL-alanine, $0.3 \mathrm{~g}$; L-aspartic acid, $0.3 \mathrm{~g}$; $\mathrm{NaNO}_{3}, 2 \mathrm{~g} ; \mathrm{KH}_{2} \mathrm{PO}_{4}$, $1 \mathrm{~g} ; \mathrm{KCl}, 0.5 \mathrm{~g} ; \mathrm{MgSO}_{4} \cdot 7 \mathrm{H}_{2} \mathrm{O}, 0.25 \mathrm{~g} ; \mathrm{FeCl}_{3} \cdot 6 \mathrm{H}_{2} \mathrm{O}, 0.01 \mathrm{~g}$; glucose, $20 \mathrm{~g}$; agar, $15 \mathrm{~g}$ and water to 1 liter ( $\mathrm{pH} \mathrm{6.0)}$ (12). Conidia formed on agar slants were washed out with sterilized $0.01 \%$ Tween 80 solution. The suspension of conidia was filtered through two sheets of gauze and diluted to a concentration of $0.2 \mathrm{mg} / \mathrm{ml}$ with water. One $\mathrm{ml}$ of the suspension was spread by glass spreader on the cellophane-covered agar medium in an aluminium box $(21 \times 14 \mathrm{~cm})$. Culture temperature was $30^{\circ}$.

Preparation of cell homogenate. Mycelial mats grown on the cellophanecovered agar media were collected and crushed with a pestle in a chilled mortar. The crushed mycelia were mixed with a small amount of $0.05 \mathrm{M}$ of sodium acetate buffer ( $\mathrm{pH} 4.5$ ) and disintegrated with a French pressure cell.

Assay of RNase. The enzyme activity was determined by the method of UCHIDA and EgAMI (13) with a slight modification. The reaction mixture contained $0.21 \mathrm{M}$ acetate buffer ( $\mathrm{pH} 4.5$ ), $4 \mathrm{mg}$ of RNA and an appropriate amount of the RNase preparation in a final volume of $0.75 \mathrm{ml}$. After incubation for $15 \mathrm{~min}$ at $37^{\circ}$, the reaction was stopped with $0.25 \mathrm{ml}$ of $0.75 \%$ uranyl acetate in $25 \%$ perchloric acid. After centrifugation at $1,000 \times g$ for $5 \mathrm{~min}$, the supernatant was diluted 26-fold with water, and the absorbance at $260 \mathrm{~nm}$ was determined. Controls were carried out by addition of the RNase solution after the addition of $0.75 \%$ uranyl acetate in $25 \%$ perchloric acid. One unit of RNase activity corresponds to the amount of enzyme necessary to cause an absorbance change of 1.0 at $260 \mathrm{~nm}$ under the conditions described above.

Analysis of the digestion products. The size of nucleotides formed from yeast RNA by digestion with acid RNase was determined by the method of NESTLE and Roberts (14). RNA was hydrolyzed at $37^{\circ}$ for $24 \mathrm{hr}$ with RNase preparation. The digest was applied to a DEAE-cellulose column $(1 \times 20 \mathrm{~cm})$ equilibrated with $0.02 \mathrm{M}$ Tris- $\mathrm{HCl}$ buffer $(\mathrm{pH} 7.5)$ containing $7 \mathrm{M}$ urea and eluted with a linear gradient of $\mathrm{NaCl}(0$ to $0.4 \mathrm{M})(15)$.

In order to identify mononucleotides formed, the first and the second peaks 
of the eluate, named peaks 0 and 1, respectively, were collected separately. Each fraction was desalted with a DEAE-cellulose column by the method of RUSHIZKY and SOBER (16) and lyophilized. The desalted sample was applied to a column $(1 \times 16 \mathrm{~cm})$ of Dowex- $1 \times 2$ (formate form) and eluted with a linear gradient of 0 to $7 \mathrm{M}$ formic acid. Peak 0 was hydrolyzed with $0.6 \mathrm{~N} \mathrm{HCl}$ at room temperature for $60 \mathrm{~min}$ before application to a column of Dowex-1. The mononucleotides were assigned by comparing their elution positions with those of four authentic nucleoside $3^{\prime}$-monophosphates and guanosine $2^{\prime}, 3^{\prime}$-cyclic monophosphate. Furthermore, this was confirmed by ultraviolet absorption spectrum of each nucleotide at various $\mathrm{pH}$, and by thin layer chromatography on cellulose powder film (solvent; $i$-propanol-saturated ammonium sulfate-0.1 $\mathrm{M}$ acetate buffer ( $\mathrm{pH} \mathrm{6.0),} \mathrm{2:} \mathrm{79:} \mathrm{19).}$

Determination of protein concentration. Protein concentration was determined by the method of LOWRY et al. (17) using bovine serum albumin as the standard.

Materials. Yeast RNA purchased from Kohjin Co. was used for RNase assays. DEAE-cellulose was purchased from Brown Co. and Dowex-1 $\times 2(200-$ 400 mesh) from Dow Chemical Co. Cellulose powder film for thin layer chromatography was a commercial thin layer film from Kodak Co. (Chromagram ${ }^{\circledR}$ with a fluorescence indicator No. 6065).

\section{RESULTS}

Purification of the two acid RNases

Mycelia of $A$. niger were grown for 3 days on the cellophane-covered agar media. Cell homogenate obtained from mycelial mat was centrifuged at $1,900 \times g$ for $10 \mathrm{~min}$. When cells were disintegrated in $0.05 \mathrm{M}$ acetate buffer ( $\mathrm{pH} 4.5$ ), neutral RNase activity ( $\mathrm{pH}$ 6.0) was found exclusively in cell debris, so that the supernatant contained only acid RNase activity. Solid ammonium sulfate was added to the supernatant. The protein precipitating between 60 and $90 \%$ saturation with ammonium sulfate was collected by centrifugation, dissolved in $0.01 \mathrm{M}$ Tris- $\mathrm{HCl}$ buffer ( $\mathrm{pH} 7.4$ ), and dialyzed against the same buffer. Dialysate was loaded on a column $(2.4 \times 17 \mathrm{~cm})$ of DEAE-cellulose and eluted with a linear gradient of sodium chloride $(0$ to $0.6 \mathrm{M})$ in $0.01 \mathrm{M}$ Tris- $\mathrm{HCl}$ buffer ( $\mathrm{pH}$ 7.4.). The enzyme was eluted in a single peak at a $0.4 \mathrm{M}$ concentration of sodium chloride in the buffer.

The enzyme fractions from DEAE-cellulose column chromatography were collected and concentrated with a collodion bag. The concentrated solution was loaded on a column $(2.5 \times 60 \mathrm{~cm})$ of Sephadex G-100 and eluted with $0.01 \mathrm{M}$ Tris$\mathrm{HCl}$ buffer ( $\mathrm{pH}$ 7.4). RNase activity was separated into two peaks designated as Aspergillus niger acid RNases I and II (Fig. 1). Each fraction was concentrated with a collodion bag and was rechromatographed on a Sephadex G-100 column $(2 \times 38 \mathrm{~cm})$ under the same conditions. The results of the purification of acid RNases I and II are summarized in Table 1. Acid RNases I and II were purified about 170- and 110-fold, respectively. Acid RNases I and II had no detectable 


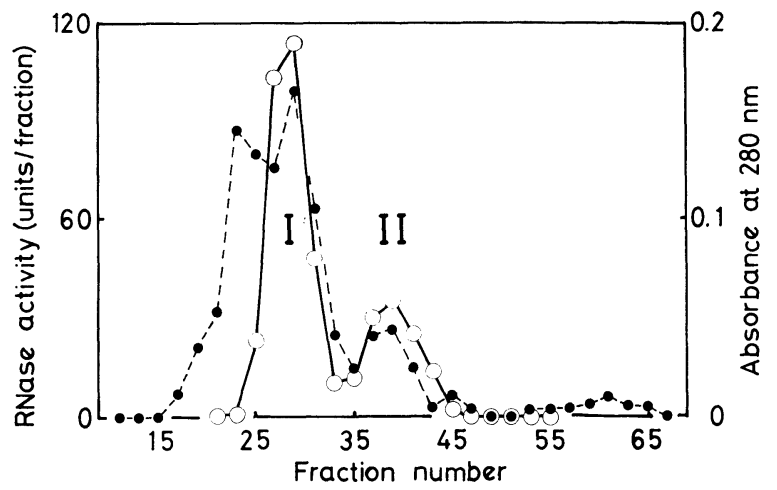

Fig. 1. Gel filtration of $A$. niger acid RNase on Sephadex G-100 column.

Roman numerals denote number of acid RNases. $O$, Acid RNase activity; absorbance at $280 \mathrm{~nm}$.

Table 1. Summary of purification procedure.

\begin{tabular}{lccc}
\hline \multicolumn{1}{c}{ Fraction } & $\begin{array}{c}\text { Total activity } \\
\text { (units) }\end{array}$ & $\begin{array}{c}\text { Total protein } \\
(\mathrm{mg})\end{array}$ & $\begin{array}{c}\text { Specific activity } \\
\text { (units/mg protein) }\end{array}$ \\
\hline Homogenate & 4,482 & 3,448 & 1.30 \\
$1,900 \times g$ supernatant & 2,791 & 1,011 & 2.76 \\
$\left(\mathrm{NH}_{4}\right)_{2} \mathrm{SO}_{4}$ precipitate $(60-90 \%$ sat.) & 1,693 & 138 & 12.3 \\
DEAE-cellulose & 1,280 & 23.2 & 55.1 \\
1st Sephadex G-100, peak I & 442 & 3.61 & 117 \\
1st Sephadex G-100, peak II & 373 & 3.73 & 100 \\
2nd Sephadex G-100, peak I & 253 & 1.16 & 219 \\
2nd Sephadex G-100, peak II & 145 & 1.01 & 141 \\
\hline
\end{tabular}

non-specific phosphomonoesterase nor phosphodiesterase activity as measured by the hydrolysis of $p$-nitrophenyl phosphate or bis- $p$-nitrophenyl phosphate, respectively. Both enzymes cleaved neither native nor heat-denatured DNA of salmon sperm origin.

\section{Properties of the two acid RNases}

Molecular weights of the two acid RNases were studied by gel filtration using a column $(2 \times 38 \mathrm{~cm})$ of Sephadex G-100 with protein standards. From elution volumes, the approximate molecular weights of acid RNases I and II were estimated to be about 45,000 and 13,000, respectively (Fig. 2).

The effect of $\mathrm{pH}$ on the activity of the two enzymes was examined with yeast RNA as substrate. As shown in Fig. 3, the optimal pH of acid RNase I was 3.5, whereas that of II was 4.5 .

The effect of temperature on the activity of the two acid RNases is presented in Fig. 4. The optimal temperature of acid RNase I was about $60^{\circ}$, whereas that of acid RNase II was about $50^{\circ}$. 


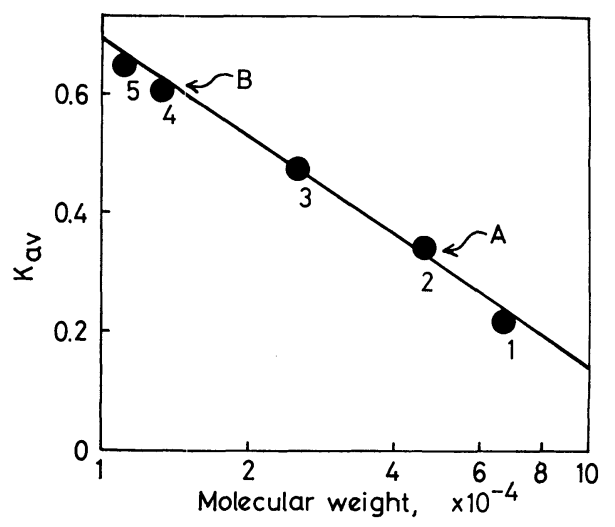

Fig. 2. Estimation of molecular weights of the two acid RNases.

The purified acid RNase samples and protein standards were loaded separately onto a column $(2 \times 38 \mathrm{~cm})$ of Sephadex G-100 and eluted with $0.1 \mathrm{M} \mathrm{NaCl}$ in $0.01 \mathrm{M}$ Tris- $\mathrm{HCl}$ buffer $(\mathrm{pH} 7.4) . \quad K_{\mathrm{av}}=\left(V_{\mathrm{e}}-V_{\mathrm{o}}\right) /\left(V_{\mathrm{t}}-V_{\mathrm{o}}\right)$, where $V_{\mathrm{e}}$ is the elution volume, $V_{\mathrm{o}}$ is the void volume determined with blue dextran 2,000 , and $V_{t}$ is the bed volume.

1, Bovine serum albumin (m.w. 67,000); 2, ovalbumin (m.w. 45,000); 3, $\alpha$-chymotryp$\sin$ (m.w. 25,000); 4, cytochrome-c (m.w. 12,900); and RNase $T_{1}$ (m.w., 11,000). The positions of the RNases were denoted by arrows: A, acid RNase I; B, acid RNase II.

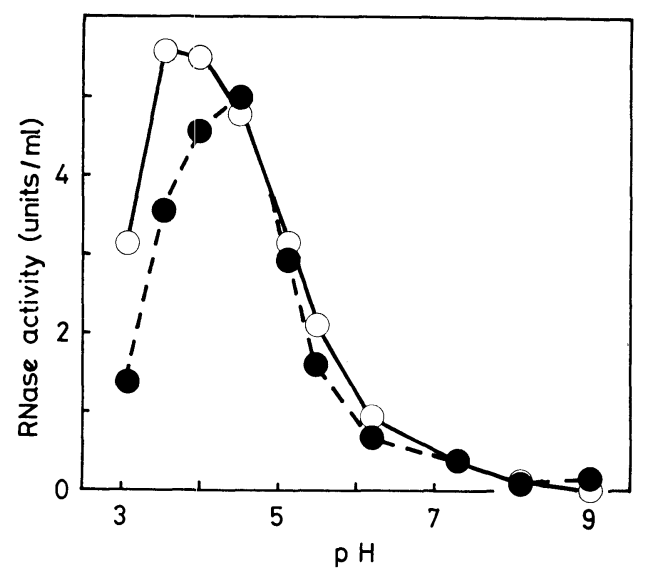

Fig. 3. Effect of $\mathrm{pH}$ on the activities of the two acid RNases.

RNase activity was determined at various $\mathrm{pHs}$ by the usual procedure. Buffers used were glycine- $\mathrm{HCl}$ buffer ( $\mathrm{pH} 3.0$ ), sodium acetate buffer ( $\mathrm{pH} 3.5-5.5)$, sodium phosphate buffer (pH 6.0-7.0), and Tris- $\mathrm{HCl}$ buffer (pH 7.5-9.0). $\bigcirc$, Acid RNase I; $\bullet$, acid RNase II.

The stability of the two enzymes was examined by determining the activity remaining after heating them at various temperatures for $10 \mathrm{~min}$. Acid RNase I lost its whole activity over $70^{\circ}$ at $\mathrm{pH} 4.5$, whereas two-thirds of the initial activity remained at $80^{\circ}$ at $\mathrm{pH}$ 7.4. On the contrary, acid RNase II was stable up to $80^{\circ}$ 


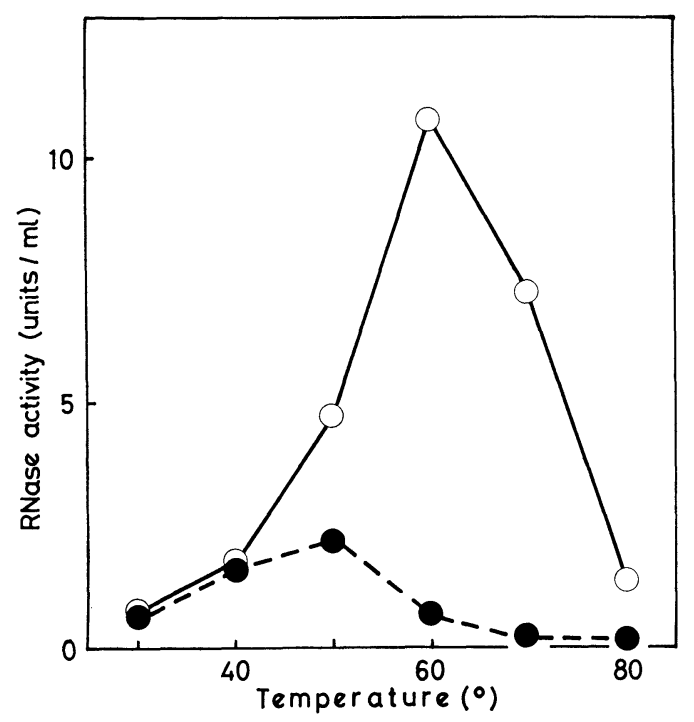

Fig. 4. Effect of temperature on the activities of the two RNases.

RNase activity was determined at various temperatures by the usual procedure. O, Acid RNase I;, , acid RNase II.

both at $\mathrm{pH} 4.5$ and 7.4. The activity of acid R Nase II seemed reversible from heat inactivation, since the enzyme activity recovered almost completely after heating it at $80^{\circ}$ although its activity was nill at temperatures higher than $70^{\circ}$.

The effects of various compounds on the enzyme activity were examined (Table 2). Both RNases were unaffected by $\mathrm{Mg}^{2+}, \mathrm{Ca}^{2+}$ or EDTA. Acid RNase I was inhibited markedly by metal ions, $\mathrm{Fe}^{3+}, \mathrm{Cu}^{2+}$ or $\mathrm{Hg}^{2+}$, and II was inhibited markedly by $\mathrm{Fe}^{3+}$. Acid RNase II was more resistant than acid RNase I to metal ions, $\mathrm{Fe}^{2+}, \mathrm{Fe}^{3+}, \mathrm{Cu}^{2+}, \mathrm{Zn}^{2+}$ or $\mathrm{Hg}^{2+}$. Both enzymes tended to be slightly activated by higher concentration of $\mathrm{KH}_{2} \mathrm{PO}_{4}$. They were slightly inhibited by spermine but not affected by SH-reagent, monoiodoacetic acid. Acid RNase I was inhibited strongly by 5 -ATP and weakly by 5'-GTP, but II was not.

\section{Time course of hydrolysis of $R N A$}

Figure 5 shows the time course of hydrolysis of yeast RNA with the two enzymes. After $24 \mathrm{hr}$ of incubation, acid RNase I hydrolyzed whole substrate RNA to acid-soluble materials, but II hydrolyzed only $33 \%$ of RNA. These results suggest some difference in base specificity of the two enzymes.

Base specificity of the two acid RNases

To determine base specificity, yeast RNA was hydrolyzed with the two acid RNases for $24 \mathrm{hr}$ at $37^{\circ}$. Digestion products with RNase I were analyzed by DEAE-cellulose chromatography in the presence of $7 \mathrm{M}$ urea. Most of the digestion 
Table 2. Effect of various compounds on activity of the two acid RNases.

\begin{tabular}{|c|c|c|c|}
\hline \multirow{2}{*}{ Reagent } & \multirow{2}{*}{$\begin{array}{c}\text { Final } \\
\text { concentration } \\
(\mathrm{mM})\end{array}$} & \multicolumn{2}{|c|}{ Residual activity ( $\%$ ) } \\
\hline & & I & II \\
\hline None & - & 100.0 & 100.0 \\
\hline $\mathrm{NaCl}$ & 100 & 92.5 & 96.7 \\
\hline $\mathrm{MgCl}_{2}$ & 1 & 100.3 & 101.8 \\
\hline $\mathrm{CaCl}_{2}$ & 10 & 91.9 & 101.0 \\
\hline $\mathrm{FeSO}_{4}$ & 1 & 70.3 & 92.6 \\
\hline $\mathrm{FeCl}_{3}$ & 1 & 7.2 & 28.1 \\
\hline $\mathrm{CuSO}_{4}$ & 1 & 12.5 & 80.3 \\
\hline $\mathrm{ZnSO}_{4}$ & 1 & 58.1 & 95.4 \\
\hline $\mathrm{HgCl}_{2}$ & 1 & 26.9 & 81.3 \\
\hline $\mathrm{KH}_{2} \mathrm{PO}_{4}$ & 10 & 114.7 & 108.7 \\
\hline EDTA & 267 & 105.3 & 106.9 \\
\hline Spermine & 10 & 84.1 & 91.8 \\
\hline $\mathrm{ICH}_{2} \mathrm{COOH}$ & 10 & 100.6 & 102.3 \\
\hline $5^{\prime}-\mathrm{ATP}$ & 0.1 & 19.7 & 98.4 \\
\hline $5^{\prime}-A D P$ & 0.1 & 91.1 & 108.8 \\
\hline $5^{\prime}$-AMP & 0.1 & 94.1 & 110.4 \\
\hline $3^{\prime}, 5^{\prime}$-сAMP & 01 & 94.4 & 100.8 \\
\hline $3^{\prime}$-AMP & 0.1 & 96.7 & 105.6 \\
\hline $5^{\prime}-$ UTP & 01 & 93.8 & 94.7 \\
\hline $5^{\prime}-\mathrm{CTP}$ & 01 & 89.5 & 104.0 \\
\hline $5^{\prime}-\mathrm{GTP}$ & 01 & 78.2 & 94.4 \\
\hline
\end{tabular}

RNase activity was determined in the presence of reagents listed above as described in MATERIALS AND METHODS.

products were found to be mononucleotides (Fig. 6-A-1). Therefore, digestion products of RNase I were directly analyzed by Dowex-1 chromatography (Fig. 6A-2). Five major peaks were eluted and identified to be cytidine $3^{\prime}$-phosphate, adenosine $3^{\prime}$-phosphate, guanosine $3^{\prime}$-phosphate, guanosine $2^{\prime}, 3^{\prime}$-cyclic phosphate and uridine $3^{\prime}$-phosphate as described in MATERIALS AND METHODS.

Since guanosine $2^{\prime}, 3^{\prime}$-cyclic phosphate disappeared when RNA was hydrolyzed with a larger amount of enzyme, this cyclic nucleotide might be an intermediate product of acid RNase I. The other three $2^{\prime}, 3^{\prime}$-cyclic nucleotides could not be detected.

DEAE-cellulose chromatography in the presence of urea revealed that digestion products of RNase II were composed of oligonucleotides of various sizes ranging from cyclic mononucleotides to more than pentanucleotides (Fig. 6-B-1). The fractions corresponding to cyclic mononucleotides (peak 0 ) and mononucleotides (peak 1) were desalted and analyzed by Dowex-1 chromatography. As shown in Fig. 6-B-2, only guanosine 2'-phosphate and guanosine 3'-phosphate were obtained from acid hydrolysis of the cyclic mononucleotide fraction (peak 0). From peak 1, guanosine 3 '-phosphate was mainly detected with small amounts of other nucleotides (Fig. 6-B-3). 


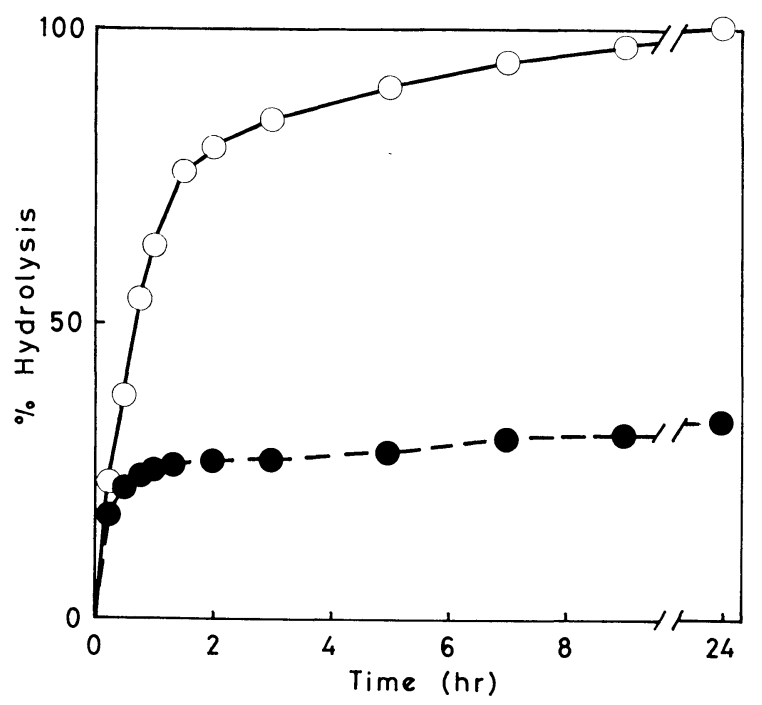

Fig. 5. Time course of hydrolysis of RNA.

RNA was hydrolyzed by the two acid RNases by the usual procedure. At the indicated time, the reaction was stopped by the addition of $0.75 \%$ uranyl acetate in $25 \%$ perchloric acid. The degree of hydrolysis was taken as the ratio of the absorbance at $260 \mathrm{~nm}$ of the acid soluble products to that obtained by alkaline hydrolysis of the same substrate. O, Acid RNase I;, , acid RNase II.

\section{Changes in the activities of acid RNases I and II with the culture age}

The activities of the two acid RNases in mycelia grown for various periods were examined with Sephadex G-100 (Fig. 7-B). Under the present conditions, the germination of conidia took place about $6 \mathrm{hr}$ after inoculation, and active growth of mycelia followed. After three days the growth reached its maximum (Fig. 7-A). The activity of acid RNase II was slightly higher than that of acid R Nase I two days after inoculation. Then, the activities of both enzymes increased sharply and reached their maxima three days after inoculation. The activity of acid RNase I remained almost unchanged until the nineteenth day, while that of II decreased and completely disappeared.

\section{DISCUSSION}

Among the RNases found to occur in fungi, two major groups of the enzymes have been highly purified and characterized (18). The first group, including RNases $T_{1}, U_{1}, N_{1}$ and $N_{3}$, consists of guanine-specific RNases. RNases of this group have molecular weights of about 10,000 and are thermostable. Acid RNase II of $A$. niger seems to belong to this group. Only the acid RNase II referred to in this paper is an acid-type RNase while the other members of this group are 


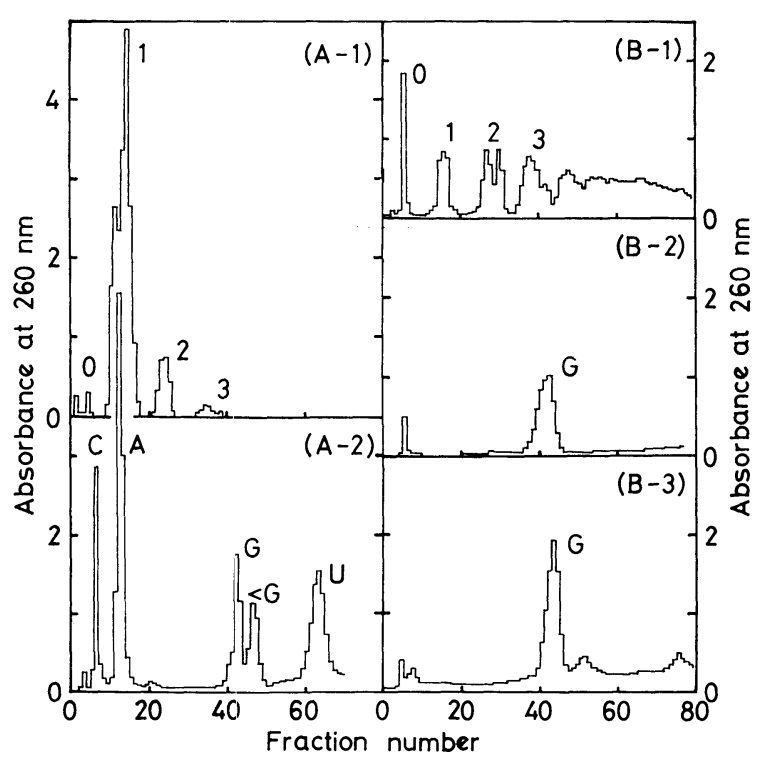

Fig. 6. Chromatographic analysis of the digestion products.

A-1. DEAE-cellulose chromatography of nucleotides formed by acid RNase I. Eight $\mathrm{mg}$ of RNA was hydrolyzed with 16 units of acid RNase 1 in $0.4 \mathrm{ml}$ of $0.2 \mathrm{M}$ acetate buffer ( $\mathrm{pH} 4.5$ ) for $24 \mathrm{hr}$. Hydrolysate was diluted with the buffer to $1.1 \mathrm{ml}$ and applied to a DEAE-cellulose column in the presence of $7 \mathrm{~m}$ urea. Arabic numerals denote peak numbers corresponding to the number of nucleotides. 0 denotes nucleoside- $2^{\prime}, 3^{\prime}$-cyclic phosphates.

A-2. Dowex-1 chromatography of nucleotides formed by acid RNase I. Eight mg of the RNA-hydrolysate was applied to a column. C, cytidine monophosphate; A, adenosine monophosphate; $\mathrm{G}$, guanosine monophosphate; $<\mathrm{G}$, guanosine $2^{\prime}, 3^{\prime}$-cyclic monophosphate and $U$, uridine monophosphate.

B-1. DEAE-cellulose chromatography of nucleotides formed by acid RNase II. Conditions were the same as those of Fig. A-1.

B-2. Dowex-1 chromatography of the peak 0 from DEAE-cellulose column (B-1). $\mathrm{G}$, guanosine monophosphate.

B-3. Dowex-1 chromatography of the peak 1 from DEAE-cellulose column (B-1). $\mathrm{G}$, guanosine monophosphate.

neutral or alkaline RNases. The second group, including RNases $T_{2}, N_{2}, L, M$, $\mathrm{U}$ and $\mathrm{R}$, consists of non-specific RNases. RNases of this group have molecular weights of 30,000-45,000 and are thermolabile. Acid RNase I of A. niger seems to belong to this group. This enzyme is quite similar to $\mathrm{RNase} \mathrm{L}$ in regard to molecular weight and various enzymatic properties such as optimal $\mathrm{pH}$, optimal temperature, and effects of inhibitors.

Most RNases mentioned above are secreted into extracellular media, while RNase $\mathrm{N}_{2}$ and $\mathrm{N}_{3}$ are intracellular enzymes. This study showed that at least a part of the acid RNases was intracellularly located in $A$. niger. In solid culture 


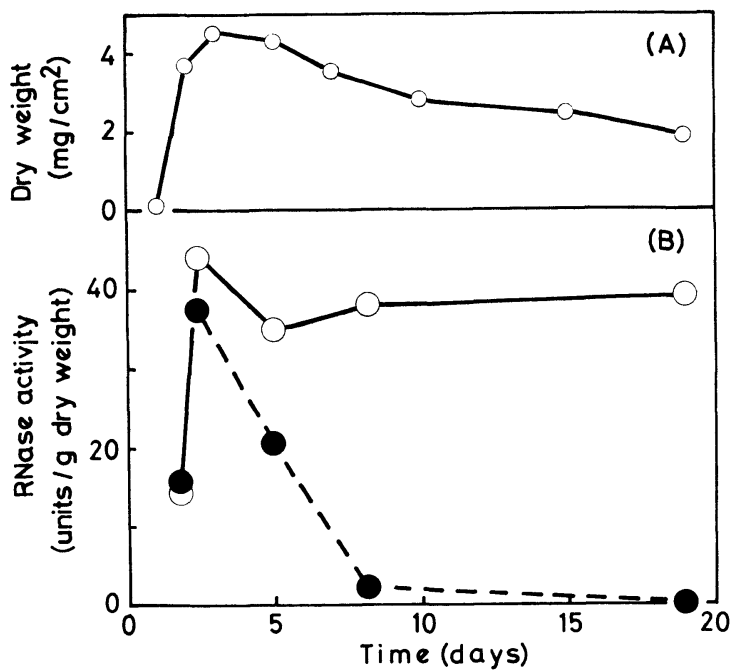

Fig. 7. Changes in (A) dry weight and (B) activities of the two acid RNases during the course of culture.

Crude cell extracts were obtained from mycelial mats grown for 2, 3, 5, 8 and 19 days. Solid ammonium sulfate was added to them at $90 \%$ saturation. The precipitated proteins


buffer, concentrated to $3 \mathrm{ml}$ and loaded on a column $(2 \times 38 \mathrm{~cm})$ of Sephadex G-100. The activities of acid RNases I and II were calculated from the chromatograms. O, Acid RNase I; •, acid RNase II. Dry weights of mycelial mats of $3.14 \mathrm{~cm}^{2}$ were measured after heating them at $110^{\circ}$ for $1 \mathrm{hr}$. Values are the means of six determinations.

used in this study RNase activity was not detected in agar medium nor on cellophane membrane. In liquid culture, however, a considerable amount of RNase activity was secreted into the culture medium (data not shown).

YAMASAKI and Arima $(19,20)$ reported that intracellular RNase of Bacillus subtilis was strongly inhibited by ATP, dATP, and ADP. They suggested that ATP is a natural regulator of $\mathrm{RNase}$ because the ATP concentration required for the inhibition of RNase is lower than the intracellular ATP concentration of the bacteria. RNase of $N$. crassa was also inhibited by ATP (21) but the inhibition required a higher concentration $(8 \mathrm{mM})$. Acid RNase I of $A$. niger was found to be specifically inhibited by ATP. This enzyme was inhibited by a relatively low concentration of ATP. So, it is likely that acid RNase I activity is regulated by intracellular ATP concentration as in the case of $B$. subtilis RNase.

Specific changes in the activities of acid and neutral RNases according to culture age have been reported by NAGASAKI (1). In the present study, the activity of two acid RNases was followed in relation to culture age of $A$. niger. The changing patterns of multiple forms of enzymes have been reported in proteases (22) and phosphatases $(23,24)$ during culture of $A$. niger. The activity of both acid 
RNases I and II increased rapidly and reached their maxima during the late phase of active growth. After their maxima, the activity of acid RNase I remained almost unchanged, while that of II decreased to zero. It is noteworthy that the activity of thermostable acid RNase II decreased while that of thermolabile acid RNase I remained unchanged.

The authors wish to express thanks to President T. Yanagita of Toyama University and Professor T. Ishikawa of the University of Tokyo for their invaluable suggestions and advice during this investigation.

\section{REFERENCES}

1) S. Nagasaki, J. Gen. Appl. Microbiol., 14, 147 (1968).

2) K. Sato and F. Egami, J. Biochem., 44, 11 (1957).

3) T. UCHIDA, J. Biochem., 60, 115 (1966).

4) M. IRIE, J. Biochem., 62, 509 (1967).

5) M. Tomoyeda, Y. Eto, and H. Horitsu, Agric. Biol. Chem., 41, 2447 (1977).

6) Y. Eto, T. Kikuchi, H. Horitsu, and M. Tomoyeda, Agric. Biol. Chem., 42,393 (1978).

7) N. TAKaI, T. Uchida, and F. Egami, Seikagaku, 39, 285 (1967).

8) N. TAKaI, T. Uchida, and F. Egami, Seikagaku, 39, 473 (1967).

9) T. Arima, T. Uchida, and F. Egami, Biochem. J., 106, 601 (1968).

10) T. Arima, T. Uchida, and F. Egami, Biochem. J., 106, 609 (1968).

11) M. Tomoyeda, Y. Eto, and T. Yoshino, Arch. Biochem. Biophys., 131, 191 (1969).

12) T. Yanagita and F. Kogané, I. Gen. Appl. Microbiol., 8, 201 (1962).

13) T. Uchida and F. Egami, In Methods in Enzymology, ed. by S. P. Colowick and N. O. Kaplan, Vol. XII, Academic Press, New York (1967), p. 228.

14) M. Nestle and W. K. Roberts, J. Biol. Chem., 244, 5219 (1967).

15) R. V. Tomlinson and G. M. Tener, J. Am. Chem. Soc., 84, 2644 (1962).

16) G. W. Rushizky and H. A. Sober, Biochim. Biophys. Acta, 55, 217 (1962).

17) O. H. Lowry, N. J. Rosebrough, A. L. Farr, and R. J. Randall, J. Biol. Chem., 193, 265 (1951).

18) T. Uchida and F. Egami, In The Enzymes, ed. by P. D. Boyer, Vol. IV, Academic Press, New York (1971), p. 205.

19) M. Yamasaki, K. Yoshida, and K. Arima, Biochim. Biophys. Acta, 209, 463 (1970).

20) M. Yamasaki and K. Arima, Biochim. Biophys. Acta, 209, 475 (1970).

21) S. R. Suskind and D. M. Bonner, Biochim. Biophys. Acta, 43, 173 (1960).

22) H. Ohhama, G. Tomonaga, and T. Yanagita, J. Biochem., 60, 713 (1966).

23) T. Komano, Plant Cell Physiol., 16, 643 (1975).

24) T. Komano, Plant Cell Physiol., 16, 659 (1975). 